\title{
Energy, macronutrient and fatty acid intake of French elderly community dwellers and association with socio-demographic characteristics: data from the Bordeaux sample of the Three-City Study
}

\author{
Catherine Féart ${ }^{1,2} *$, Marthe A. Jutand ${ }^{1,2}$, Sophie Larrieu ${ }^{1,2}$, Luc Letenneur ${ }^{1,2}$, Cécile Delcourt ${ }^{1,2}$, \\ Nicole Combe ${ }^{3}$ and Pascale Barberger-Gateau ${ }^{1,2}$ \\ ${ }^{1}$ INSERM, U593, Equipe Epidémiologie de la Nutrition et des Comportements Alimentaires, Université Bordeaux 2, ISPED \\ case 11, 146 rue Léo-Saignat, F-33076 Bordeaux Cedex, France \\ ${ }^{2}$ Université Bordeaux 2, Bordeaux, F-33076 France \\ ${ }^{3}$ Université Bordeaux 1, ITERG, Département de Biochimie-Nutrition, Talence, F-33400 France
}

(Received 10 November 2006 - Revised 4 April 2007 - Accepted 5 April 2007)

Few data are available regarding dietary habits of the elderly, in particular about fatty acid consumption, whereas these are major risk or protective factors of several age-related diseases. The aim of the present study was to characterise the dietary intake of a French elderly population in terms of energy, macronutrients and fatty acids based on their socio-demographic characteristics. The study population (age range 67.7-94.9 years) consisted of 1786 subjects from Bordeaux (France), included in the Three-City cohort. Dietary assessment was performed by a $24 \mathrm{~h}$ recall, allowing the estimation of energy, protein, carbohydrate, total fat, SFA, MUFA and PUFA intakes. Socio-demographic characteristics (age, sex, marital status, educational level and income), practice of sports and BMI were registered. Total energy intake (EI) was lower in women and in older participants ( $\geq 85$ years) but higher in single subjects. Higher EI was associated with higher income, but not with educational level. Mean contribution of macronutrients to EI (protein $18 \%$, carbohydrate $46 \%$ and total fat $31 \%$ ) was higher in women than men, except for alcohol. The oldest individuals consumed less protein and more mono- and disaccharides. Excess saturated fat intake (43\% of total fat), associated with a relative deficit in MUFA consumption ( $36 \%$ of total fat), was observed. The mean $18: 2 n-6: 18: 3 n-3$ ratio was 9.9 and decreased with higher educational level. The present results suggest that being female, older age, being widowed and low income level could be considered as risk factors of inadequate dietary intake.

Cohort studies: Nutrition: Ageing: Fatty acids

The increasingly higher life expectancy observed in developed countries is in most part attributed to a decline of mortality at older ages. Besides considerable improvement in healthcare of older individuals, better living conditions and, in particular, healthy dietary practices, may explain this greater longevity ${ }^{1}$. In addition to the general recommendations for adults, the older population has specific nutritional requirements in order to avoid protein-energy malnutrition and also more subtle deficiencies due to imbalanced diets. In particular, there is a growing interest in the putative protective effects of $n-3$ PUFA against $\mathrm{CVD}^{2}$, cancer ${ }^{3}$ and neuro-psychiatric disorders $^{4}$, such as dementia ${ }^{5}$ or depression ${ }^{6}$, whose incidence sharply increases with age. The respective essential fatty acid precursors of the $n-3(18: 3 n-3 ; \alpha$-linolenic acid) and $n-6$ (18:2n-6; linoleic acid) families cannot be endogenously synthesised and must therefore be provided by diet. The dietary ratio of essential fatty acids (n-6:n-3) must also be considered. This has led to the recommendation of about $2 \%$ of total energy for adults provided by $18: 2 n-6,1 \%$ by $18: 3 n-3$ and $0 \cdot 3 \%$ by EPA and DHA taken together (with at least $0.05 \%$ each) ${ }^{7,8}$. Knowing that the biosynthesis of long-chain PUFA occurs only at a very low rate in young adults as in the elderly ${ }^{9}$, and that experimental evidence indicates that the activity of the desaturase enzyme, which converts essential precursors in longer-chain PUFA, might be decreased in ageing ${ }^{10,11}$, the needs for EPA and DHA must be mostly covered by way of diet. Therefore, the evaluation of the adequacy of fatty acid intake in the older population requires an estimation of the dietary intake of both precursors and long-chain PUFA. However, few data have been published regarding dietary fat intake of free-living elderly individuals and insufficient data are available on the actual intake of individual PUFA in human populations. Moreover, a good knowledge of dietary patterns is necessary to improve dietary counselling provided to high-risk individual groups whose characteristics have yet to be identified.

In France, where life expectancy is among the highest in the world $^{12}$, very few epidemiological studies have focused on nutrient intake of representative samples of elderly community dwellers. Surveys of the food habits of the French population

Abbreviations: EI, energy intake.

* Corresponding author: Dr Catherine Féart, fax +33 5575714 86, email Catherine.Feart@isped.u-bordeaux2.fr 
were conducted in 1998-9 and in 2002 in representative samples but they did not include individuals over age 75 years $^{13}$. The SU.VI.MAX study reported very detailed data on dietary fat intake of French adults but did not include subjects over age 60 years ${ }^{14}$. Therefore, we lack data on fatty acid intake of the elderly, whereas this might contribute to the particularly high life expectancy ${ }^{15}$ and low CHD mortality rate observed in France (the so-called 'French paradox') ${ }^{16}$.

The aim of the present study was to describe patterns of energy and macronutrient intakes and their link to sociodemographic characteristics in a population-based sample of elderly community dwellers in south-western France, with a special focus on dietary fat intake.

\section{Subjects and methods}

The data come from the Three-City Study, a prospective cohort study of vascular risk factors of dementia whose methodology is described in detail elsewhere ${ }^{17,18}$. The protocol of the Three-City Study was approved by the Consultative Committee for the Protection of Persons participating in Biomedical Research of the Kremlin-Bicêtre University Hospital (Paris, France). To be eligible for recruitment into the Three-City Study, individuals had to be (a) living in Bordeaux, Dijon or Montpellier (three French cities), (b) aged 65 years and over and (c) not institutionalised. A personal letter was sent to each potential subject inviting them to participate and including a brief description of the study protocol and an acceptance and refusal form. Subjects from the Bordeaux sample were randomly chosen from the electoral rolls of ten districts of the urban area of Bordeaux in order to ensure a representative socio-economical variability. Hence, a sample of 9294 community dwellers was selected in 1999-2000 from the electoral rolls of Bordeaux ( $n$ 2104), Dijon ( $n$ 4931 ) and Montpellier ( $n$ 2259). All participants signed a written consent. The baseline (wave 1) data collection included socio-demographic information, lifestyle, symptoms and complaints, main chronic conditions, neuropsychological testing, a physical examination and a blood sampling. The present study is based on the second wave (wave 2) of data collection conducted in 2001-2 in Bordeaux, which placed a particular emphasis on nutritional data.

\section{Dietary assessment}

In Bordeaux, 1811 individuals already visited at wave 1 participated in the nutritional survey included in wave 2 of the Three-City Study. We did not intend to be representative of the whole Three-City cohort but of the Bordeaux sample. All these participants were visited at home by one of the four specifically trained dietitians who administered a FFQ and a $24 \mathrm{~h}$ dietary recall during a face-to-face interview. These dietitians received a collective training and monitoring to optimise the standardisation of the nutritional interviews. The $24 \mathrm{~h}$ recall was used to estimate nutrient intake. During the $24 \mathrm{~h}$ recall the dietitian registered all the meals and beverages consumed in a period of exactly $24 \mathrm{~h}$ before the subject awoke on the day of the interview. No weekend day was recorded. Quantities were assessed according to a book of photographs ${ }^{19}$ edited for the SU.VI.MAX study ${ }^{20}$. The book showed three portion sizes for each food and proposed two intermediate categories plus one below the smallest one and one above the largest one; i.e. seven portion sizes were available for each of the 236 foods or beverages. A table gave the correspondence between the portion size and the weight of the food item. Photographs of dishes and glasses with the corresponding volume were also available. The same dietitian then entered the data of the $24 \mathrm{~h}$ recall in the BILNUT ${ }^{\circledR}$ software (SCDA Nutrisoft, Cerelles, France) to obtain an estimation of the daily nutrient intake of each participant. Food composition tables for France ${ }^{21}$ are included in the BILNUT $^{\circledR}$ software. Detailed data for fatty acids from the food composition and nutrition tables edited by Souci et al. ${ }^{22}$ were added. As the $24 \mathrm{~h}$ recall was open-ended, additional data were found by consulting a French table developed by the Institut National de la Santé et de la Recherche Médicale (INSERM) and the University of Montreal ${ }^{23}$, the United States Department of Agriculture National Nutrient Database, on food packaging, and by contact with food manufacturers. Some specific data for fatty acids were directly provided by the Institut des Corps Gras - Centre Technique Industriel (ITERG) in Bordeaux.

The results are expressed in quantities and in proportion of total energy intake (EI) with or without alcohol. For fatty acids, results are also expressed in percentage of total fat.

As suggested by Willett et al. ${ }^{24}$ the validity of dietary questionnaires was assessed by the evaluation of the association between total fat intake estimated from the $24 \mathrm{~h}$ recall and $\ln (\mathrm{TAG})$ assessed at wave $1^{24}$.

\section{Other variables}

Age was recorded at the time of the dietary survey. Three age groups were defined as follows: less than 75 years, between 75 and 84 years and 85 years and over. Socio-demographic information recorded at wave 1 included sex and education (in four classes: no education or primary school only, secondary (middle) school, high school, vocational school or university). Socio-demographic characteristics also included marital status (married, divorced or separated, widowed, single), and income in five categories (less than €750, €750 to €1500, $€ 1500$ to $€ 2250$, more than $€ 2250$ per month and refuse to answer). Individuals who did not know their monthly income were added to the group of subjects who refused to answer this question.

Practice of physical exercise was assessed between waves 1 and 2 on a self-administered questionnaire by two questions: 'Do you practise sports?' (yes or no) and 'Do you perspire when you practise sports?' (never, sometimes, most of the time, always). A three-level variable was computed to describe intensity of physical exercise: no physical exercise (answer no to the first question); moderate intensity (answer yes to the first question and never or sometimes to the second one); high intensity (answer yes to the first question and most of the time or always to the second one). Subjects who did not answer the first question were represented in another group ('no answer').

Height $(\mathrm{m})$ was measured at wave 1 . Weight $(\mathrm{kg})$ was measured by the dietitian at the time of the dietary survey. BMI was computed as the weight/height ${ }^{2}$ ratio and then grouped in five categories (less than 21, 21-23, 23-27, 27-30 and more than $30 \mathrm{~kg} / \mathrm{m}^{2}$ ) according to Guigoz et al. ${ }^{25}$ and Heiat et al. ${ }^{26}$ as previously established by Deschamps et $a l^{27}$. 
The calculation of the BMR (MJ/d) was predicted using Henry's equations based on age, sex and body weight ${ }^{28}$. For men aged 60-69.9 years, the equation used is $\mathrm{BMR}=0.0543$ weight +2.37 ; for men aged 70 years and over, $\mathrm{BMR}=0.0573$ weight +2.01 . For women aged 60 69.9 years, the equation used is $\mathrm{BMR}=0.0429$ weight +2.39 ; for women aged 70 years and over, $\mathrm{BMR}=0.0417$ weight $+2 \cdot 41$.

The macronutrient and fatty acid intakes were compared with the French $\mathrm{RDA}^{8}$ and, for $20: 5 n-3$, with the recommended levels of EPA intake of Simopoulos et al. ${ }^{7}$.

\section{Statistical methods}

Intakes of energy and macronutrients were described by their mean, standard deviation, median and quartiles. The cross-sectional associations of total EI and nutrient intake with sociodemographic characteristics of the participants were assessed by Student's $t$ test (when comparing two categories) or by ANOVA (when comparing more than two categories) followed by Dunnett's post hoc tests to compare means of categories with one of them taken as the reference group. Dunnett's statistical significance was accepted at $P<0 \cdot 05$. Stepwise backward linear regression was used to identify the socio-demographic variables associated with total EI. The normal distribution of EI was verified since the mean and the median were similar and the mean \pm 2 SD included about $95 \%$ of the total EI of the subjects.

The SAS statistical package (version 9.1; SAS Institute Inc., Cary, NC, USA) was used for these analyses.

\section{Results}

After exclusion of twenty-two participants who gave incomplete information on the $24 \mathrm{~h}$ recall and three with extremely low reported EI (less than $2000 \mathrm{~kJ} / \mathrm{d}$ ), the sample included 1786 participants aged 67 (range 67.7-94.9) years and over (62.7\% women, mean age 76.8 years and $37.3 \%$ men, mean age 76.1 years). Their total EI based on their socio-demographic characteristics is given in Table 1. Men had a significantly higher EI mean than women $(8389$ v. $6335 \mathrm{~kJ}$; $P<0.0001$ ). Mean EI was significantly lower after age 85 years, for widowed individuals and for individuals with incomes below €750. Mean EI was significantly higher in participants with a higher educational level (significant Dunnett's tests).

The total EI was described based on BMI and the practice of physical exercise (Table 2). Weight and height data were absent in 152 subjects. In the remaining 1634 participants, total EI was not significantly different between the five predefined categories of BMI of the whole population, as was the case in men, although the EI was lower in the group of subjects whose BMI was the highest. However, the reported EI was significantly higher in women with BMI higher than $23 \mathrm{~kg} / \mathrm{m}^{2}$ (significant Dunnett's test). As expected, the mean EI significantly increased with the intensity of the practice of physical exercise.

Since all these socio-demographic characteristics are closely linked, they were entered as dummy explanatory variables in a multilinear regression model on total EI (Table 3). In the whole population, female sex and age 85 years and over were significantly related to a lower EI whereas being

Table 1. Total energy intake based on socio-demographic characteristics of elderly community dwellers from Bordeaux (France), 2001-2002

\begin{tabular}{|c|c|c|c|c|c|c|c|c|}
\hline \multirow[b]{2}{*}{ Socio-demographic characteristic } & \multirow[b]{2}{*}{$n$} & \multicolumn{7}{|c|}{ Energy intake (kJ) } \\
\hline & & Mean & SD & 1st quartile & Median & 3rd quartile & Range & $P \dagger$ \\
\hline Total & 1786 & 7100 & 2272 & 5427 & 6933 & 8556 & 2176,16900 & \\
\hline $\begin{array}{l}\text { Sex } \\
\text { Men } \\
\text { Women }\end{array}$ & $\begin{array}{r}1786 \\
666 \\
1120\end{array}$ & $\begin{array}{l}8389 \\
6335\end{array}$ & $\begin{array}{l}2243 \\
1912\end{array}$ & $\begin{array}{l}6983 \\
5004\end{array}$ & $\begin{array}{l}8242 \\
6130\end{array}$ & $\begin{array}{l}9774 \\
7422\end{array}$ & $\begin{array}{l}3046,16900 \\
2176,14519\end{array}$ & $<0.0001$ \\
\hline $\begin{array}{l}\text { Age (years) } \\
\quad<75 \text { (reference group) } \\
75-84 \\
\geq 85\end{array}$ & $\begin{array}{r}1786 \\
769 \\
904 \\
113\end{array}$ & $\begin{array}{l}7259 \\
7025 \\
6594\end{array}$ & $\begin{array}{l}2368 \\
2180 \\
2230\end{array}$ & $\begin{array}{l}5494 \\
5418 \\
5050\end{array}$ & $\begin{array}{l}7037 \\
6912 \\
6381\end{array}$ & $\begin{array}{l}8719 \\
8460 \\
7858\end{array}$ & $\begin{array}{l}2200,16900 \\
2176,15322 \\
2498,13146\end{array}$ & 0.006 \\
\hline $\begin{array}{l}\text { Marital status } \\
\text { Married (reference group) } \\
\text { Divorced or separated } \\
\text { Widowed } \\
\text { Single }\end{array}$ & $\begin{array}{r}1782 \\
946 \\
141 \\
577 \\
118\end{array}$ & $\begin{array}{l}7506 \\
7054 \\
6448 \\
7125\end{array}$ & $\begin{array}{l}2218 \\
2335 \\
2155 \\
2410\end{array}$ & $\begin{array}{l}5895 \\
5197 \\
4954 \\
5335\end{array}$ & $\begin{array}{l}7268 \\
7029 \\
6121 \\
6979\end{array}$ & $\begin{array}{l}8941 \\
8510 \\
7719 \\
8519\end{array}$ & $\begin{array}{l}2351,15322 \\
2335,13644 \\
2176,14343 \\
2402,16900\end{array}$ & $<0.0001$ \\
\hline $\begin{array}{l}\text { Education } \\
\text { No or primary (reference group) } \\
\text { Secondary } \\
\text { High school } \\
\text { University }\end{array}$ & $\begin{array}{r}1777 \\
619 \\
479 \\
366 \\
313\end{array}$ & $\begin{array}{l}6791 \\
7058 \\
7234 \\
7594\end{array}$ & $\begin{array}{l}2159 \\
2163 \\
2397 \\
2389\end{array}$ & $\begin{array}{l}5243 \\
5468 \\
5456 \\
5824\end{array}$ & $\begin{array}{l}6699 \\
6933 \\
7000 \\
7385\end{array}$ & $\begin{array}{l}8021 \\
8481 \\
8749 \\
9100\end{array}$ & $\begin{array}{l}2200,14975 \\
2276,15192 \\
2176,16900 \\
2347,14494\end{array}$ & $<0.0001$ \\
\hline $\begin{array}{l}\text { Monthly income }(€) \\
<750 \text { (reference group) } \\
750-1500 \\
1500-2250 \\
\geq 2250 \\
\text { Refused to answer }\end{array}$ & $\begin{array}{r}1786 \\
139 \\
545 \\
434 \\
519 \\
149\end{array}$ & $\begin{array}{l}6167 \\
6736 \\
7226 \\
7623 \\
7113\end{array}$ & $\begin{array}{l}2008 \\
2180 \\
2234 \\
2322 \\
2297\end{array}$ & $\begin{array}{l}4720 \\
5188 \\
5427 \\
5837 \\
5619\end{array}$ & $\begin{array}{l}5996 \\
6468 \\
7058 \\
7456 \\
7004\end{array}$ & $\begin{array}{l}7372 \\
8000 \\
8569 \\
9100 \\
8514\end{array}$ & $\begin{array}{l}2200,13506 \\
2402,14518 \\
2176,16900 \\
2598,15192 \\
2276,15322\end{array}$ & $\begin{array}{l}<0.0001 \\
* \\
* \\
* \\
*\end{array}$ \\
\hline
\end{tabular}

${ }^{*}$ Mean value was significantly different from that of the reference group $(P<0.05$; Dunnett's test).

†By ANOVA comparing mean energy intake. 
Table 2. Total energy intake based on body mass index and physical exercise of elderly community dwellers from Bordeaux (France), 2001-2002

\begin{tabular}{|c|c|c|c|c|c|c|c|c|}
\hline \multirow[b]{2}{*}{ Variable } & \multirow[b]{2}{*}{$n$} & \multicolumn{7}{|c|}{ Energy intake (kJ) } \\
\hline & & Mean & SD & 1st quartile & Median & 3rd quartile & Range & $P \dagger$ \\
\hline BMI $\left(\mathrm{kg} / \mathrm{m}^{2}\right)$ & 1634 & & & & & & & 0.10 \\
\hline \multicolumn{9}{|l|}{ All subjects } \\
\hline$<21$ & 181 & 7259 & 2293 & 5519 & 7063 & 8648 & 2874,15322 & \\
\hline $21-23$ & 249 & 7155 & 2167 & 5594 & 6945 & 8468 & 2176,13510 & \\
\hline $23-27$ & 669 & 7293 & 2222 & 5627 & 7138 & 8757 & 2347,15192 & \\
\hline $27-30$ & 322 & 7088 & 2406 & 5259 & 6837 & 8807 & 2276,14974 & \\
\hline$\geq 30$ & 213 & 6824 & 2289 & 5259 & 6586 & 8180 & 2335,16900 & \\
\hline Men & 635 & & & & & & & $0 \cdot 16$ \\
\hline$<21$ & 33 & 8502 & 2464 & 6895 & 8594 & 9464 & 3824,15322 & \\
\hline $21-23$ & 63 & 9067 & 2130 & 7372 & 8899 & 10636 & 4912,13510 & \\
\hline $23-27$ & 294 & 8318 & 2113 & 7071 & 8167 & 9531 & 3046,15192 & \\
\hline $27-30$ & 164 & 8326 & 2310 & 6586 & 8230 & 9924 & 3339,14974 & \\
\hline$\geq 30$ & 81 & 8284 & 2351 & 6786 & 8138 & 9447 & 3230,16900 & \\
\hline Women & 999 & & & & & & & $<0.0001$ \\
\hline$<21$ (reference group) & 148 & 6983 & 2167 & 5364 & 6908 & 8217 & 2874,13297 & \\
\hline $21-23$ & 186 & 6506 & 1766 & 5322 & 6280 & 7460 & 2176,11594 & \\
\hline $23-27$ & 375 & 6489 & 1958 & 5146 & 6381 & 7519 & 2347,14518 & * \\
\hline $27-30$ & 158 & 5803 & 1475 & 4481 & 5489 & 6971 & 2276,11184 & * \\
\hline$\geq 30$ & 132 & 5925 & 1724 & 4699 & 5636 & 6966 & 2335,11104 & * \\
\hline Physical exercise & 1786 & & & & & & & $<0.0001$ \\
\hline No (reference group) & 923 & 7004 & 2226 & 5343 & 6858 & 8297 & 2402,16900 & \\
\hline Moderate & 288 & 7468 & 2435 & 5640 & 7205 & 8874 & 2176,15322 & * \\
\hline Intensive & 122 & 7971 & 2469 & 6075 & 7598 & 9916 & 3230,14343 & * \\
\hline No answer & 453 & 6824 & 2121 & 5268 & 6707 & 8196 & 2200,14974 & \\
\hline
\end{tabular}

${ }^{*}$ Mean value was significantly different from that of the reference group $(P<0.05$; Dunnett's test).

†B ANOVA comparing mean energy intake.

single, having a monthly income greater than $€ 2250$ or unknown were associated with a higher EI. There was no significant association of EI with educational level. The model explained $20 \%$ of total variance of EI (adjusted $R^{2}$ ). Given that dietary intakes of men are significantly higher than those of women, we performed the analyses of the association between EI and socio-demographic characteristics stratified by sex. As in the whole population, education was not associated with EI in men or in women. However, a significant interaction between sex and education $(P=0 \cdot 015)$ was found. Although no significant association was observed for each educational level, the coefficients were in the opposite direction in men and women. Mean EI tended to decrease drastically with age in men whereas a lowest decrease was observed only in the oldest women. EI was significantly related to marital status in women, with a noticeable decreased intake in widowed women. The association between income and EI showed similar trends in men and women.

In comparison with the recommendation concerning EI $(125 \mathrm{~kJ} / \mathrm{kg}$ per $\mathrm{d}), 73.1 \%$ of the subjects on average, and mainly women, had an insufficient daily EI $(70.4 \%$ of men v. $74.8 \%$ of women; $P=0.046)$. This proportion did not vary significantly between the three age groups defined previously (ANOVA; $P=0 \cdot 57$ ). The total reported EI was lower than the estimated BMR for $20.2 \%$ of men and $27.2 \%$ of women.

Intake of macronutrients based on sex is given in Table 4. The macronutrient intakes expressed in $\mathrm{g} / \mathrm{d}$ were all significantly different between men and women. Men had a higher intake of every macronutrient in terms of quantities but, when expressed in proportion of EI, they had a lower intake of protein $(P<0.0001)$, carbohydrate $(P<0.0001)$, with significant differences between the mono- and disaccharide and polysaccharide intakes, and total fat $(P=0 \cdot 017)$, mainly saturated fat $(P=0 \cdot 006)$. Concerning alcohol, men had a higher alcohol intake $(P<0.0001)$ than women as expressed in $\mathrm{g} / \mathrm{d}$ or in proportion of EI. Alcohol was an important component of total EI since the mean daily intake of alcohol was 21.6 (range $0.0-115 \cdot 2$ ) $\mathrm{g}$ in men and 6.9 (range $0 \cdot 0-76 \cdot 8) \mathrm{g}$ in women. In men, $70.5 \%$ of proteins were of animal origin $v .72 \cdot 1 \%$ for women $(P=0.007)$.

Table 5 reports the intake of macronutrients based on age in three groups. Mean consumption of alcohol was not different between the three age groups $(P=0 \cdot 19)$. The intake of macronutrients expressed in proportion of EI based on age in three groups showed that protein intake decreased with age (ANOVA; $P=0.007$ ) notably after 85 years (significant Dunnett's test). This is particularly true for proteins of animal origins (ANOVA; $P=0.013$ ) but less marked for the proteins of vegetable origins (ANOVA; $P=0 \cdot 044$ ). Furthermore, there was no difference in total carbohydrate intake between the three age groups (ANOVA; $P=0 \cdot 12$ ). Nevertheless, the consumption of mono- and disaccharides significantly increased with age (ANOVA; $P=0 \cdot 001$ ), notably after 75 years (significant Dunnett's test). The consumption of carbohydrates (46\% of EI on average) was below recommended levels (about 50 to $55 \%$ of daily total EI provided by carbohydrates) for almost $63 \%$ of the subjects. Concerning fat intake, there were no significant differences between the three age groups in terms of total fat, saturated fat, MUFA or PUFA intake. As expected, the total fat intake reported at wave 2 was inversely linked to $\ln (\mathrm{TAG})$ levels $(r-0.05 ; P=0.038)$. 
Table 3. Influence of socio-demographic characteristics on total energy intake in a multilinear regression model in the whole study population of elderly community dwellers from Bordeaux (France) and stratified by sex $(n$ 1773)

\begin{tabular}{|c|c|c|c|c|c|c|c|c|c|}
\hline \multirow[b]{2}{*}{ Socio-demographic characteristic } & \multicolumn{3}{|c|}{ Whole population } & \multicolumn{3}{|c|}{ Men } & \multicolumn{3}{|c|}{ Women } \\
\hline & $\beta$ Coefficient & $95 \% \mathrm{Cl}$ & $P$ & $\beta$ Coefficient & $95 \% \mathrm{Cl}$ & $P$ & B Coefficient & $95 \% \mathrm{Cl}$ & $P$ \\
\hline \multicolumn{10}{|l|}{ Sex } \\
\hline Men (reference group) & & & $<0.0001$ & & & & & & \\
\hline Women & -1970 & $-2184,-1754$ & $<0.0001$ & & & & & & \\
\hline \multicolumn{10}{|l|}{ Age (years) } \\
\hline$\leq 75$ (reference group) & & & 0.08 & & & $0 \cdot 11$ & & & $0 \cdot 10$ \\
\hline $75-84$ & -50 & $-250,150$ & 0.62 & -309 & $-663,45$ & 0.09 & 142 & $-99,383$ & 0.25 \\
\hline$\geq 85$ & -470 & $-882,-58$ & 0.025 & -617 & $-1389,154$ & $0 \cdot 12$ & -330 & $-809,148$ & 0.18 \\
\hline \multicolumn{10}{|l|}{ Marital status } \\
\hline Married (reference group) & & & 0.002 & & & 0.64 & & & 0.001 \\
\hline Divorced or separated & 391 & 3,779 & 0.048 & 453 & $-419,1325$ & 0.31 & 262 & $-172,696$ & 0.24 \\
\hline Widowed & -123 & $-376,131$ & 0.34 & 147 & $-357,652$ & 0.57 & -289 & $-585,6$ & 0.055 \\
\hline Single & 572 & 154, 991 & 0.007 & 441 & $-634,1517$ & 0.42 & 448 & $-3,899$ & 0.051 \\
\hline \multicolumn{10}{|l|}{ Education } \\
\hline No or primary (reference group) & & & 0.86 & & & $0 \cdot 10$ & & & 0.37 \\
\hline Secondary & -2 & $-256,251$ & 0.98 & -166 & $-658,324$ & 0.50 & 96 & $-193,384$ & 0.52 \\
\hline High school & 107 & $-176,391$ & 0.46 & 363 & $-173,899$ & 0.18 & -59 & $-388,270$ & 0.72 \\
\hline University & 7 & $-316,329$ & 0.97 & -232 & $-788,324$ & 0.41 & 291 & $-122,704$ & 0.17 \\
\hline \multicolumn{10}{|l|}{ Monthly income $(€)$} \\
\hline$<750$ (reference group) & & & 0.064 & & & 0.66 & & & 0.21 \\
\hline $750-1500$ & 195 & $-195,584$ & 0.33 & 31 & $-1463,1526$ & 0.97 & 196 & $-189,583$ & 0.32 \\
\hline $1500-2250$ & 290 & $-142,723$ & 0.19 & 229 & $-1282,1739$ & 0.77 & 184 & $-273,640$ & 0.43 \\
\hline$\geq 2250$ & 521 & 58,984 & 0.027 & 390 & $-1133,1913$ & 0.61 & 481 & $-24,987$ & 0.06 \\
\hline Refused to answer & 587 & 91,1082 & 0.020 & 560 & $-1072,2192$ & 0.50 & 483 & $-29,995$ & 0.06 \\
\hline
\end{tabular}


Table 4. Macronutrient intake based on sex of elderly community dwellers from Bordeaux (France), 2001-2002 ( $n$ 1786)

\begin{tabular}{|c|c|c|c|c|c|c|c|c|c|c|c|}
\hline \multirow[b]{2}{*}{ Nutrient } & \multicolumn{5}{|c|}{ Intake (g/d) } & \multicolumn{3}{|c|}{ Proportion of total EI (\%) } & \multicolumn{3}{|c|}{$\begin{array}{c}\text { Proportion of El without } \\
\text { alcohol (\%) }\end{array}$} \\
\hline & Mean & SD & 1st quartile & Median & 3rd quartile & Mean & SD & $P^{*}$ & Mean & SD & $P^{*}$ \\
\hline Alcohol & $12 \cdot 4$ & $16 \cdot 2$ & 0.0 & $7 \cdot 2$ & $19 \cdot 2$ & 4.7 & 5.8 & $<0.0001$ & & & \\
\hline Men & $21 \cdot 6$ & $20 \cdot 1$ & $5 \cdot 8$ & $17 \cdot 6$ & $32 \cdot 0$ & 7.5 & $6 \cdot 6$ & & - & & \\
\hline Women & 6.9 & $10 \cdot 0$ & 0.0 & 1.9 & $11 \cdot 3$ & $3 \cdot 1$ & 4.4 & & - & & \\
\hline Proteins & 74.9 & 26.9 & 55.4 & 71.4 & $90 \cdot 6$ & $18 \cdot 0$ & 4.7 & $<0.0001$ & 18.9 & 4.9 & 0.067 \\
\hline Men & $85 \cdot 0$ & $27 \cdot 2$ & $66 \cdot 3$ & $82 \cdot 8$ & $101 \cdot 2$ & $17 \cdot 2$ & 4.3 & & $18 \cdot 7$ & 4.7 & \\
\hline Women & 68.9 & 24.8 & $51 \cdot 7$ & 65.5 & 83.0 & $18 . \overline{5}$ & 4.9 & & $19 \cdot 1$ & $5 \cdot 1$ & \\
\hline Animal proteins & 53.5 & $24 \cdot 0$ & $36 \cdot 4$ & $49 \cdot 8$ & $66 \cdot 4$ & $12 \cdot 9$ & $5 \cdot 0$ & $<0.0001$ & $13 \cdot 6$ & $5 \cdot 3$ & 0.009 \\
\hline Men & $59 \cdot 9$ & $25 \cdot 0$ & $43 \cdot 2$ & 55.9 & 74.6 & $12 \cdot 2$ & 4.5 & & $13 \cdot 2$ & $5 \cdot 0$ & \\
\hline Women & $49 \cdot 7$ & $22 \cdot 6$ & $34 \cdot 1$ & 46.5 & $62 \cdot 0$ & $13 \cdot 4$ & $5 \cdot 3$ & & $13 \cdot 8$ & $5 \cdot 5$ & \\
\hline Vegetable proteins & 21.4 & $9 \cdot 1$ & $15 \cdot 1$ & $20 \cdot 3$ & $26 \cdot 3$ & $5 \cdot 1$ & 1.6 & 0.63 & $5 \cdot 3$ & $1 \cdot 6$ & 0.006 \\
\hline Men & $25 \cdot 1$ & $9 \cdot 2$ & $19 \cdot 2$ & 23.9 & $30 \cdot 1$ & $5 \cdot 0$ & 1.4 & & 5.5 & 1.5 & \\
\hline Women & $19 \cdot 2$ & 8.2 & $13 \cdot 6$ & $17 \cdot 7$ & $23 \cdot 4$ & $5 \cdot 1$ & 1.7 & & $5 \cdot 2$ & 1.7 & \\
\hline Carbohydrates & 194.0 & $70 \cdot 0$ & $144 \cdot 8$ & $187 \cdot 3$ & 233.9 & $46 \cdot 1$ & $9 \cdot 8$ & $<0.0001$ & $48 \cdot 4$ & 9.5 & 0.96 \\
\hline Men & $223 \cdot 3$ & $73 \cdot 1$ & $172 \cdot 7$ & $216 \cdot 8$ & 263.9 & 44.8 & $9 \cdot 7$ & & 48.4 & 9.4 & \\
\hline Women & $176 \cdot 5$ & $61 \cdot 8$ & 133.5 & $171 \cdot 3$ & $213 \cdot 2$ & $46 \cdot 9$ & $9 \cdot 7$ & & $48 \cdot 4$ & $9 \cdot 6$ & \\
\hline Mono- and disaccharides & $89 \cdot 1$ & 39.9 & $61 \cdot 2$ & $83 \cdot 7$ & 111.5 & $21 \cdot 7$ & $8 \cdot 7$ & $<0.0001$ & $22 \cdot 7$ & $8 \cdot 8$ & $<0.0001$ \\
\hline Men & $96 \cdot 1$ & $44 \cdot 3$ & $64 \cdot 0$ & 89.9 & $121 \cdot 0$ & 19.5 & $8 \cdot 2$ & & $21 \cdot 0$ & 8.5 & \\
\hline Women & $85 \cdot 0$ & $36 \cdot 4$ & $59 \cdot 0$ & $80 \cdot 3$ & $106 \cdot 3$ & 23.0 & $8 \cdot 7$ & & $23 \cdot 7$ & 8.9 & \\
\hline Polysaccharides & $104 \cdot 8$ & $49 \cdot 6$ & $70 \cdot 2$ & 98.9 & 134.4 & 24.5 & $8 \cdot 2$ & 0.0003 & $25 \cdot 7$ & 8.4 & $<0.0001$ \\
\hline Men & $127 \cdot 2$ & $51 \cdot 1$ & 92.9 & $122 \cdot 3$ & $155 \cdot 0$ & $25 \cdot 4$ & $7 \cdot 6$ & & $27 \cdot 4$ & $7 \cdot 7$ & \\
\hline Women & 91.5 & 43.5 & $60 \cdot 9$ & $87 \cdot 3$ & $114 \cdot 8$ & $24 \cdot 0$ & 8.4 & & $24 \cdot 7$ & $8 \cdot 6$ & \\
\hline Total fat & 59.4 & 27.5 & 40.5 & $54 \cdot 1$ & 74.4 & $31 \cdot 1$ & $8 \cdot 7$ & 0.017 & $32 \cdot 7$ & $9 \cdot 0$ & 0.30 \\
\hline Men & $69 \cdot 0$ & $29 \cdot 7$ & $47 \cdot 7$ & $64 \cdot 3$ & 85.4 & 30.5 & 8.5 & & 33.0 & $9 \cdot 0$ & \\
\hline Women & $53 \cdot 7$ & $24 \cdot 3$ & $36 \cdot 8$ & $49 \cdot 6$ & $67 \cdot 4$ & 31.5 & 8.9 & & 32.5 & $9 \cdot 1$ & \\
\hline Saturated fat & $25 \cdot 5$ & 12.9 & $16 \cdot 1$ & $23 \cdot 2$ & 32.6 & $13 \cdot 3$ & 4.6 & 0.006 & $14 \cdot 0$ & $4 \cdot 8$ & 0.88 \\
\hline Men & 29.5 & $13 \cdot 8$ & $19 \cdot 7$ & $27 \cdot 4$ & 37.6 & $13 \cdot 0$ & 4.2 & & $14 \cdot 0$ & 4.5 & \\
\hline Women & $23 \cdot 2$ & $11 \cdot 8$ & 14.9 & $21 \cdot 1$ & 29.6 & $13 \cdot 6$ & 4.8 & & 14.0 & 4.9 & \\
\hline MUFA & $21 \cdot 2$ & $10 \cdot 9$ & $13 \cdot 4$ & $19 \cdot 0$ & $27 \cdot 6$ & $11 \cdot 1$ & 3.9 & 0.30 & 11.6 & 4.2 & 0.10 \\
\hline Men & 24.8 & $12 \cdot 1$ & $16 \cdot 1$ & $22 \cdot 1$ & 30.7 & $10 \cdot 9$ & 4.0 & & 11.8 & $4 \cdot 3$ & \\
\hline Women & $19 \cdot 0$ & 9.5 & $12 \cdot 4$ & $17 \cdot 2$ & $24 \cdot 1$ & $11 \cdot 1$ & 3.9 & & 11.5 & $4 \cdot 1$ & \\
\hline PUFA & 8.4 & $6 \cdot 0$ & 4.8 & 6.9 & $10 \cdot 1$ & 4.4 & $2 \cdot 6$ & 0.37 & $4 \cdot 7$ & $2 \cdot 7$ & 0.45 \\
\hline Men & 9.8 & $6 \cdot 6$ & $5 \cdot 8$ & 8.3 & 11.9 & 4.4 & $2 \cdot 4$ & & 4.7 & $2 \cdot 6$ & \\
\hline Women & $7 \cdot 6$ & 5.5 & 4.4 & $6 \cdot 3$ & 9.0 & 4.5 & $2 \cdot 7$ & & $4 \cdot 6$ & $2 \cdot 8$ & \\
\hline
\end{tabular}

El, energy intake.

${ }^{\star}$ By Student's $t$ test comparing alcohol and macronutrient intakes as proportions of energy intake with or without alcohol consumption between men and women.

The proportion of participants with a daily intake of proteins below the recommended value of $1 \mathrm{~g} / \mathrm{kg}$ body weight per $\mathrm{d}$ was $44.1 \%$ with a slight and insignificant difference between men $(41.4 \%)$ and women $(45.7 \% ; P=0.07)$. There was no significant effect of age on this proportion $(43.4 \%$ of subjects under age 75 years; $43.9 \%$ of subjects aged between 75 and 84 years and $50.5 \%$ of those aged 85 years and over; $P=0 \cdot 37$ ).

Fatty acid intake is described in Table 6 . The main contributor to fat intake in proportion of EI was $18: 1 n-9$ (oleic acid), followed by 16:0 (palmitic acid). The mean consumption of $18: 2 n-6(3.35 \%$ of EI) was just below recommended levels ( $4 \%$ of EI) whereas the mean $18: 3 n-3$ intake $(0.40 \%$ of EI) was half the recommendation $(0.8 \%$ of EI). The $18: 2 n-6: 18: 3 n-3$ ratio ( $9 \cdot 90$ on average) was twice as high as the recommended threshold of 5 , which corresponded to approximately the first quartile. Concerning the long-chain $n$-3 PUFA, the intake of EPA ( $0.07 \%$ of EI) was below recommended levels according to Simopoulos et al. $(0.1 \%$ of EI) ${ }^{7}$. Moreover, $61.6 \%$ of the subjects consumed less than $50 \%$ of the recommended DHA intake (about $0.05 \%$ of EI); however, the mean consumption of DHA as a proportion of EI $(0.15 \%)$ was about three-fold above recommended levels. This intake of DHA highlights the great inter-individual variability observed, which is also shown for EPA but less obvious for 20:4n-6 (arachidonic acid).

The consumption of $18: 2 n-6$ and $18: 3 n-3$ PUFA and the $18: 2 n-6: 18: 3 n-3$ ratio based on socio-demographic characteristics are described in Table 7 . There was no significant difference in the proportion of each $n-6$ and $n$-3 PUFA precursor as a proportion of EI according to sex, age group and education or income levels. Compared with married individuals, being widowed was significantly linked to a lower $18: 2 n-6$ intake, but not to $18: 3 n-3$ intake, as expressed as a percentage of EI (significant Dunnett's test). The 18:2n-6: 18:3n-3 ratio was significantly associated with educational level (ANOVA; $P=0 \cdot 011$ ), with a significant difference between the least educated participants who had the highest ratio and the subjects with secondary or high school, but not university, levels (significant Dunnett's test). The $18: 2 n-6: 18: 3 n-3$ ratio did not change according to sex, age, marital status and income. Concerning long-chain $n$ - 6 PUFA, the intake of $20: 4 n-6 \quad(\mathrm{~g} / \mathrm{d})$ was lower in women than in men $(P<0.0001)$ and significantly decreased as age increased (ANOVA; $P=0 \cdot 011)$. The intake of $20: 5 n-3(\mathrm{~g} / \mathrm{d})$ significantly increased with higher income levels (ANOVA; $P=0 \cdot 044)$. When the long-chain $n-6$ or $n$-3 PUFA intakes were expressed as proportions of EI, there was no significant 
Table 5. Macronutrient intake based on age of elderly community dwellers from Bordeaux (France), 2001-2002 ( $n$ 1786)

\begin{tabular}{|c|c|c|c|c|c|c|c|c|c|c|c|}
\hline \multirow[b]{2}{*}{ Variable } & \multicolumn{5}{|c|}{ Intake (g/d) } & \multicolumn{3}{|c|}{ Proportion of total El (\%) } & \multicolumn{3}{|c|}{$\begin{array}{c}\text { Proportion of El without } \\
\text { alcohol (\%) }\end{array}$} \\
\hline & Mean & SD & 1st quartile & Median & 3rd quartile & Mean & SD & $P \dagger$ & Mean & SD & $P \dagger$ \\
\hline Alcohol & & & & & & & & 0.19 & & & \\
\hline$<75$ years & $13 \cdot 3$ & $17 \cdot 7$ & 0.0 & $7 \cdot 7$ & $19 \cdot 2$ & 4.9 & $6 \cdot 0$ & & - & & \\
\hline $75-84$ years & $12 \cdot 0$ & $15 \cdot 3$ & 0.0 & $7 \cdot 4$ & $19 \cdot 2$ & 4.7 & $5 \cdot 6$ & & - & & \\
\hline$\geq 85$ years & 9.5 & $12 \cdot 2$ & 0.0 & 4.8 & $16 \cdot 0$ & 3.9 & 4.9 & & - & & \\
\hline Proteins & & & & & & & & 0.007 & & & 0.002 \\
\hline$<75$ years & $77 \cdot 8$ & $27 \cdot 7$ & 57.9 & 74.9 & 93.4 & $18 \cdot 3$ & $4 \cdot 8$ & & $19 \cdot 3$ & $5 \cdot 0$ & \\
\hline 75-84years & $73 \cdot 6$ & $25 \cdot 9$ & $55 \cdot 4$ & $70 \cdot 0$ & 88.8 & $17 \cdot 9$ & $4 \cdot 7$ & & $18 \cdot 8$ & 4.9 & * \\
\hline$\geq 85$ years & $66 \cdot 1$ & $26 \cdot 1$ & $48 \cdot 2$ & $60 \cdot 8$ & $79 \cdot 4$ & $17 \cdot 0$ & $4 \cdot 3$ & * & $17 \cdot 7$ & 4.5 & * \\
\hline Animal sources & & & & & & & & 0.013 & & & 0.006 \\
\hline$<75$ years & $55 \cdot 7$ & $25 \cdot 0$ & 38.4 & 51.9 & 69.5 & $13 \cdot 2$ & $5 \cdot 2$ & & $13 \cdot 9$ & 5.4 & \\
\hline $75-84$ years & $52 \cdot 7$ & 23.1 & $35 \cdot 6$ & $49 \cdot 6$ & $65 \cdot 1$ & $12 \cdot 9$ & $5 \cdot 0$ & & 13.5 & $5 \cdot 2$ & \\
\hline$\geq 85$ years & $45 \cdot 7$ & $22 \cdot 6$ & $28 \cdot 4$ & 41.4 & 58.6 & 11.7 & $4 \cdot 2$ & * & $12 \cdot 2$ & 4.5 & * \\
\hline Vegetable sources & & & & & & & & 0.044 & & & 0.043 \\
\hline$<75$ years & $22 \cdot 1$ & $9 \cdot 4$ & $15 \cdot 5$ & $20 \cdot 8$ & $27 \cdot 3$ & $5 \cdot 1$ & $1 \cdot 6$ & & $5 \cdot 4$ & 1.7 & \\
\hline $75-84$ years & $20 \cdot 9$ & 8.8 & 14.8 & $20 \cdot 0$ & 25.5 & $5 \cdot 0$ & 1.5 & & $5 \cdot 2$ & 1.6 & * \\
\hline$\geq 85$ years & 20.5 & 8.4 & $14 \cdot 2$ & $19 \cdot 6$ & $26 \cdot 2$ & $5 \cdot 3$ & 1.6 & & 5.5 & 1.7 & \\
\hline Carbohydrates & & & & & & & & 0.12 & & & 0.23 \\
\hline$<75$ years & $197 \cdot 3$ & 73.4 & $145 \cdot 2$ & $190 \cdot 0$ & 238.5 & $45 \cdot 8$ & $9 \cdot 8$ & & $48 \cdot 1$ & 9.5 & \\
\hline $75-84$ years & $192 \cdot 0$ & 67.5 & $145 \cdot 0$ & $184 \cdot 3$ & 231.4 & $46 \cdot 2$ & 9.9 & & $48 \cdot 4$ & $9 \cdot 8$ & \\
\hline$\geq 85$ years & $186 \cdot 3$ & 63.7 & $144 \cdot 0$ & 183.4 & $225 \cdot 5$ & $47 \cdot 8$ & 8.2 & & $49 \cdot 8$ & 7.9 & \\
\hline Mono- and disaccharides & & & & & & & & 0.001 & & & 0.003 \\
\hline$<75$ years & $88 \cdot 3$ & $40 \cdot 4$ & $59 \cdot 1$ & 84.6 & $112 \cdot 6$ & 20.9 & 8.4 & & 21.9 & $8 \cdot 6$ & \\
\hline $75-84$ years & $90 \cdot 0$ & 39.7 & $62 \cdot 3$ & 83.0 & 111.6 & $22 \cdot 1$ & 8.9 & * & $23 \cdot 1$ & $9 \cdot 0$ & * \\
\hline$\geq 85$ years & 88.3 & 37.5 & $63 \cdot 7$ & $82 \cdot 0$ & 103.4 & 23.4 & $8 \cdot 8$ & * & $24 \cdot 2$ & $8 \cdot 7$ & * \\
\hline Polysaccharides & & & & & & & & 0.08 & & & 0.06 \\
\hline$<75$ years & $109 \cdot 0$ & 51.7 & $72 \cdot 7$ & $101 \cdot 8$ & $138 \cdot 8$ & $25 \cdot 0$ & $8 \cdot 1$ & & $26 \cdot 2$ & $8 \cdot 3$ & \\
\hline $75-84$ years & $102 \cdot 1$ & $47 \cdot 8$ & $69 \cdot 2$ & $98 \cdot 0$ & $129 \cdot 8$ & $24 \cdot 1$ & 8.2 & & $25 \cdot 3$ & 8.5 & * \\
\hline$\geq 85$ years & $98 \cdot 0$ & $46 \cdot 3$ & $64 \cdot 1$ & $95 \cdot 1$ & $131 \cdot 0$ & 24.5 & $7 \cdot 8$ & & $25 \cdot 5$ & $8 \cdot 1$ & \\
\hline Total fat & & & & & & & & 0.70 & & & 0.83 \\
\hline$<75$ years & $60 \cdot 2$ & $25 \cdot 6$ & $40 \cdot 1$ & 54.4 & $75 \cdot 5$ & 30.9 & $8 \cdot 6$ & & $32 \cdot 6$ & $9 \cdot 0$ & \\
\hline $75-84$ years & $59 \cdot 3$ & 27.5 & $40 \cdot 8$ & $54 \cdot 2$ & 74.4 & $31 \cdot 3$ & 8.9 & & $32 \cdot 8$ & $9 \cdot 3$ & \\
\hline$\geq 85$ years & 55.6 & $27 \cdot 1$ & 37.5 & 52.5 & 64.9 & 31.3 & $7 \cdot 8$ & & 32.5 & 7.9 & \\
\hline Saturated fat & & & & & & & & 0.13 & & & 0.25 \\
\hline$<75$ years & $25 \cdot 7$ & $12 \cdot 8$ & $16 \cdot 1$ & $23 \cdot 3$ & 33.4 & $13 \cdot 1$ & 4.5 & & $13 \cdot 8$ & 4.6 & \\
\hline $75-84$ years & $25 \cdot 5$ & $13 \cdot 0$ & $16 \cdot 2$ & $23 \cdot 3$ & 32.5 & $13 \cdot 4$ & 4.7 & & $14 \cdot 1$ & 4.9 & \\
\hline$\geq 85$ years & $25 \cdot 0$ & $13 \cdot 8$ & $15 \cdot 2$ & $21 \cdot 8$ & 30.3 & 13.9 & $4 \cdot 4$ & & 14.5 & 4.4 & \\
\hline MUFA & & & & & & & & 0.50 & & & 0.33 \\
\hline$<75$ years & 21.8 & $11 \cdot 1$ & $13 \cdot 8$ & $19 \cdot 6$ & $27 \cdot 6$ & $11 \cdot 2$ & 4.0 & & 11.8 & $4 \cdot 2$ & \\
\hline $75-84$ years & $20 \cdot 9$ & 11.8 & $13 \cdot 3$ & $18 \cdot 7$ & $26 \cdot 2$ & 11.0 & 3.9 & & 11.6 & 4.1 & \\
\hline$\geq 85$ years & $19 \cdot 1$ & 9.9 & $12 \cdot 8$ & $17 \cdot 1$ & $24 \cdot 0$ & $10 \cdot 8$ & $3 \cdot 8$ & & 11.3 & 3.9 & \\
\hline PUFA & & & & & & & & 0.42 & & & 0.45 \\
\hline$<75$ years & $8 \cdot 4$ & $5 \cdot 8$ & $5 \cdot 1$ & $7 \cdot 0$ & $10 \cdot 0$ & 4.4 & $2 \cdot 4$ & & 4.6 & 2.5 & \\
\hline $75-84$ years & 8.6 & $6 \cdot 3$ & 4.6 & 6.9 & $10 \cdot 2$ & 4.5 & $2 \cdot 8$ & & 4.7 & 2.9 & \\
\hline$\geq 85$ years & 7.5 & 4.8 & 4.4 & $6 \cdot 6$ & $9 \cdot 3$ & 4.3 & $2 \cdot 1$ & & 4.4 & $2 \cdot 3$ & \\
\hline
\end{tabular}

El, energy intake.

${ }^{*}$ Mean value was significantly different from that of the reference group (subjects aged less than 75 years) $(P<0.05$; Dunnett's test).

†B ANOVA comparing alcohol and macronutrient intakes as proportions of El with or without alcohol consumption among the three age groups.

association with the socio-demographic characteristics studied (data not shown).

\section{Discussion}

In the present cross-sectional study, we observed a significant association between total EI and several socio-demographic characteristics such as age, sex, marital status, levels of income, but not educational level, in a multivariate analysis. Despite an adequate intake of total fat, our findings indicate an excessive intake of saturated fat concomitant to a relative deficit of MUFA intake according to the current French recommendations. Being widowed was significantly associated with lower $18: 2 n-6$ PUFA intakes as expressed as a percentage of EI. The $18: 2 n-6: 18: 3 n-3$ ratio was linked to education.

The accuracy of food-intake assessment is crucial in dietary studies $^{29,30}$. In the present study, a single $24 \mathrm{~h}$ recall was used to assess the dietary EI as a surrogate measure of the total quantity of food intake even if this method presents limitations. Indeed, it cannot capture long-term dietary intake patterns for each subject because of high intra-individual variation. Thus, a reported single day of intake is unlikely to be representative of usual individual intake. However, if sample sizes are sufficiently large, it may be used to determine average intake in defined subgroups of a population ${ }^{31}$. Moreover, it is usually recognised that the mean total EI was generally underestimated with such methodology 32 . Indeed, we 
Table 6. Fatty acid intake of elderly community dwellers from Bordeaux (France), 2001-2002 ( $n$ 1786)

\begin{tabular}{|c|c|c|c|c|c|c|c|c|c|}
\hline \multirow[b]{2}{*}{ Fatty acid } & \multicolumn{2}{|c|}{ Intake (g/d) } & \multicolumn{2}{|c|}{$\begin{array}{l}\text { Proportion of total } \\
\text { fat intake (\%) }\end{array}$} & \multicolumn{5}{|c|}{ Proportion of total energy intake (\%) } \\
\hline & Mean & SD & Mean & SD & Mean & SD & 1st quartile & Median & 3rd quartile \\
\hline $14: 0$ & $2 \cdot 85$ & 1.82 & $4 \cdot 80$ & $2 \cdot 12$ & 1.49 & 0.77 & 0.92 & 1.41 & 1.93 \\
\hline $16: 0$ & $12 \cdot 71$ & 6.69 & $21 \cdot 22$ & 4.33 & 6.63 & 2.41 & 4.96 & 6.35 & 7.93 \\
\hline $18: 0$ & 5.43 & $3 \cdot 21$ & $9 \cdot 11$ & 3.07 & 2.85 & 1.29 & 1.97 & $2 \cdot 65$ & 3.48 \\
\hline $16: 1 n-7$ & 1.53 & 1.60 & 2.49 & 1.79 & 0.78 & 0.67 & 0.48 & 0.65 & 0.89 \\
\hline $18: 1 n-9$ & $18 \cdot 22$ & $9 \cdot 85$ & $30 \cdot 32$ & $6 \cdot 78$ & 9.55 & 3.77 & $6 \cdot 86$ & 8.96 & $11 \cdot 75$ \\
\hline Total $n-6$ PUFA & $6 \cdot 55$ & $5 \cdot 27$ & $11 \cdot 15$ & $6 \cdot 51$ & 3.44 & $2 \cdot 36$ & $2 \cdot 00$ & $2 \cdot 79$ & $4 \cdot 07$ \\
\hline $18: 2 n-6$ & $6 \cdot 38$ & $5 \cdot 23$ & $10 \cdot 86$ & 6.48 & 3.35 & 2.35 & 1.91 & $2 \cdot 70$ & 3.97 \\
\hline $20: 4 n-6$ & $0 \cdot 16$ & 0.17 & 0.29 & 0.34 & 0.09 & 0.09 & 0.02 & 0.06 & 0.13 \\
\hline Total $n$-3 PUFA & 1.23 & 1.40 & $2 \cdot 17$ & $2 \cdot 34$ & 0.65 & 0.69 & 0.30 & 0.43 & 0.63 \\
\hline $18: 3 n-3$ & 0.78 & 0.80 & 1.30 & 0.84 & 0.40 & 0.32 & 0.25 & 0.33 & 0.44 \\
\hline EPA & 0.14 & 0.34 & 0.26 & 0.66 & 0.07 & 0.18 & 0.00 & 0.00 & 0.05 \\
\hline $\mathrm{DHA}$ & 0.28 & 0.69 & 0.54 & 1.35 & 0.15 & 0.38 & 0.00 & 0.02 & $0 \cdot 10$ \\
\hline $18: 2 n-6: 18: 3 n-3$ ratio & 9.90 & 7.05 & - & - & - & - & - & - & - \\
\hline
\end{tabular}

observed a relatively high proportion of subjects who declared to consume less than $125 \mathrm{~kJ} / \mathrm{kg}$ body weight per d. However, in only $4 \%$ of men and $6 \%$ of women, the reported EI was under $80 \%$ of the estimated BMR. In other studies, the intakes recorded in reports were more than $20 \%$ below the estimated $\mathrm{BMR}^{33}$. Nevertheless, the validity of the BMR estimation seems to be questionable in the sample studied of the very elderly ${ }^{34,35}$.

Even so, mean total EI observed in this sample of French elderly community dwellers is very close to the figures reported in elderly participants (mean age 77 years) in the New Mexico Aging Process Study (8698 kJ (2079 kcal) for men and $6251 \mathrm{~kJ}$ (1494 kcal) for women), although the methodology of the dietary survey differed ${ }^{36}$. Furthermore, in the EPIC-Elderly study, Bamia et al. reported that among almost 100000 individuals aged 60 years and over living in nine European countries, the mean EI estimated by FFQ ranged from 8135 to $10820 \mathrm{~kJ}$ for men and from 5945 to $9439 \mathrm{~kJ}$ for women ${ }^{37}$. The mean EI estimated in the present study was also close to that observed by Drewnowski et al. in French community dwellers aged 65 years and over ${ }^{38}$. In addition, the food photographs, as used here, generally have a positive influence on the relative validity for absolute food group intake ${ }^{39}$. In the present study, the mean EI was positively associated with the intensity of the practice of physical exercise. Altogether, these observations allowed us to validate the methodology employed in the present study to estimate the mean EI and macronutrient intake for this group of elderly subjects.

The decreased mean EI in the oldest group might be due in part to dental and digestive disturbances which increase with age $^{40,41}$. A decrease of perceived attractiveness of food with increased age in terms of taste, appetite and palatability of food was also commonly admitted ${ }^{42,43}$. As already observed in the literature ${ }^{30,44}$, there was a trend to lowest EI for the subjects who had the highest BMI. The low energy reporters with high BMI may be individuals who have difficulties estimating their actual food intake. They are also more likely to be dieters or they tend to have higher levels of energy restraint ${ }^{44,45}$. Since the present study is cross-sectional, we cannot assert that the socio-demographic characteristics identified as markers of unbalanced dietary patterns are responsible for this poor dietary pattern. Moreover, the differences in mean EI with marital status described in this sample of subjects already enrolled in the Three-City cohort were expected. Indeed, according to the FFQ administered to all participants of the Three-City Study at wave 1, subjects living alone had poorer dietary habits ${ }^{18}$. However, the association between mean EI and educational level already demonstrated in the Three-City cohort at wave 1 disappeared in the present study when adjusted on the other socio-demographic characteristics. This result could be in part due to the association of income with EI because of the collinearity between income and educational level. The association between income and dietary habits was not assessed at wave 1 in the Three-City Study ${ }^{18}$. An association between energy density and diet cost was also demonstrated in a population of 837 French adults ${ }^{46}$. Altogether, these results obtained at wave 1 in the Three-City cohort and wave 2 in this Bordeaux sample suggest that these particular socio-demographic characteristics are associated with a specific dietary pattern. According to these studies and others, these lifestyle characteristics, which are known to be associated with age-related disorders such as cognitive decline or dementia ${ }^{47}$, should be considered as potential confounding factors in the relationship between nutritional and pathological status in older individuals. However, since the present study is cross-sectional and because of the methodology employed, some associations between EI and socio-demographic characteristics could be due to chance findings. This could partly explain why some of these associations disappeared in men or in women when they were analysed separately by sex. Moreover, another explanation is that stratifying on sex may also have generated insufficient statistical power to detect associations.

In comparison with the French $\mathrm{RDA}^{8}$, the food patterns in this sample of the French elderly seem to be low in carbohydrates, rich in proteins and acceptable for total fatty acids, yet showing an excess in saturated fat and deficiency in MUFA intakes. The decreased consumption of polysaccharides with age might be due in part to changes in behaviour with advanced age, suggesting that the elderly have a greater taste for sweet foods. A previous study on dietary patterns prevailing among the elderly across Europe reported that the 'sweet- and fat-dominated' diet reflected the choice of older 
Table 7. $n-6$ and $n-3$ Polyunsaturated fatty acid intakes and 18:2n-6:18:3n-3 ratio based on socio-demographic characteristics (sex, age, marital status, education, income) of elderly community dwellers from Bordeaux (France), 2001-2002 ( $n$ 1786)

\begin{tabular}{|c|c|c|c|c|c|c|c|c|c|c|c|c|c|c|c|}
\hline \multirow[b]{3}{*}{ Socio-demographic characteristic } & \multicolumn{6}{|c|}{$18: 2 n-6$} & \multicolumn{6}{|c|}{$18: 3 n-3$} & \multicolumn{3}{|c|}{$18: 2 n-6: 18: 3 n-3$ ratio } \\
\hline & \multicolumn{3}{|c|}{ Intake (g/d) } & \multicolumn{3}{|c|}{ Proportion of total El (\%) } & \multicolumn{3}{|c|}{ Intake $(g / d)$} & \multicolumn{3}{|c|}{ Proportion of total EI (\%) } & \multirow[b]{2}{*}{ Mean } & \multirow[b]{2}{*}{ SD } & \multirow[b]{2}{*}{$P \dagger$} \\
\hline & Mean & SD & $P \dagger$ & Mean & SD & $P \dagger$ & Mean & SD & $P \dagger$ & Mean & SD & $P \dagger$ & & & \\
\hline Sex & & & $<0.0001$ & & & 0.75 & & & $<0.0001$ & & & 0.92 & & & 0.54 \\
\hline Men & $7 \cdot 50$ & $5 \cdot 70$ & & 3.33 & $2 \cdot 17$ & & 0.92 & 0.92 & & 0.40 & 0.33 & & $9 \cdot 78$ & 6.03 & \\
\hline Women & 5.72 & $4 \cdot 82$ & & $3 \cdot 36$ & $2 \cdot 45$ & & 0.69 & 0.70 & & 0.40 & 0.32 & & 9.97 & 7.59 & \\
\hline Age (years) & & & 0.30 & & & 0.43 & & & 0.15 & & & 0.29 & & & $0 \cdot 70$ \\
\hline$<75$ & $6 \cdot 36$ & 4.98 & & $3 \cdot 29$ & $2 \cdot 19$ & & 0.78 & 0.76 & & 0.39 & 0.30 & & $9 \cdot 75$ & $6 \cdot 50$ & \\
\hline $75-84$ & 6.49 & 5.54 & & 3.42 & $2 \cdot 52$ & & 0.79 & 0.86 & & 0.41 & 0.35 & & $10 \cdot 00$ & 7.44 & \\
\hline$\geq 85$ & 5.69 & $4 \cdot 33$ & & $3 \cdot 21$ & 1.96 & & 0.64 & 0.42 & & 0.36 & 0.18 & & $10 \cdot 19$ & 7.42 & \\
\hline Marital status & & & $<0.0001$ & & & 0.034 & & & 0.002 & & & 0.42 & & & 0.57 \\
\hline Married (reference group) & 7.02 & $5 \cdot 71$ & & 3.50 & $2 \cdot 51$ & & 0.84 & 0.89 & & 0.41 & 0.36 & & $10 \cdot 07$ & $6 \cdot 67$ & \\
\hline Divorced or separated & $5 \cdot 91$ & 4.04 & & $3 \cdot 20$ & 2.02 & & 0.75 & 0.58 & & 0.40 & 0.28 & & 9.41 & 6.48 & \\
\hline Widowed & 5.52 & $4 \cdot 70$ & * & $3 \cdot 16$ & $2 \cdot 22$ & * & 0.70 & 0.73 & * & 0.39 & 0.29 & & 9.66 & $7 \cdot 79$ & \\
\hline Single & $6 \cdot 17$ & $4 \cdot 37$ & & $3 \cdot 22$ & 1.95 & & 0.68 & 0.39 & & 0.36 & 0.18 & & $10 \cdot 08$ & $6 \cdot 60$ & \\
\hline Education & & & 0.90 & & & 0.07 & & & 0.15 & & & 0.95 & & & 0.011 \\
\hline No or primary (reference group) & 6.42 & 4.91 & & 3.55 & 2.49 & & 0.73 & 0.67 & & 0.39 & 0.29 & & $10 \cdot 64$ & $7 \cdot 87$ & \\
\hline Secondary & $6 \cdot 26$ & 5.05 & & $3 \cdot 27$ & $2 \cdot 12$ & & 0.78 & 0.74 & & 0.40 & 0.29 & & 9.45 & 6.58 & * \\
\hline High school & $6 \cdot 38$ & $5 \cdot 69$ & & $3 \cdot 26$ & $2 \cdot 43$ & & $0 \cdot 81$ & 0.90 & & 0.41 & 0.35 & & $9 \cdot 35$ & $6 \cdot 15$ & * \\
\hline University & 6.54 & $5 \cdot 66$ & & $3 \cdot 21$ & $2 \cdot 33$ & & 0.84 & 0.96 & & 0.40 & 0.38 & & 9.83 & 6.95 & \\
\hline Monthly income $(€)$ & & & 0.006 & & & 0.77 & & & 0.021 & & & 0.74 & & & 0.44 \\
\hline$<750$ (reference group) & $5 \cdot 30$ & 3.63 & & 3.24 & 2.09 & & 0.63 & 0.44 & & 0.38 & 0.22 & & $10 \cdot 16$ & 7.84 & \\
\hline $750-1500$ & 5.99 & 4.60 & & 3.35 & $2 \cdot 34$ & & 0.72 & 0.68 & & 0.40 & 0.29 & & 9.94 & 7.53 & \\
\hline $1500-2250$ & $6 \cdot 71$ & 5.39 & * & 3.45 & $2 \cdot 36$ & & 0.80 & 0.83 & & 0.40 & 0.31 & & $10 \cdot 13$ & $7 \cdot 19$ & \\
\hline$\geq 2250$ & $6 \cdot 82$ & $5 \cdot 68$ & * & $3 \cdot 34$ & $2 \cdot 41$ & & 0.83 & 0.86 & * & 0.40 & 0.36 & & 9.89 & 6.44 & \\
\hline Refused to answer & $6 \cdot 37$ & $6 \cdot 32$ & & $3 \cdot 18$ & 2.44 & & 0.86 & 1.03 & * & 0.43 & 0.40 & & 8.89 & 5.92 & \\
\hline
\end{tabular}

El, energy intake.

${ }^{*}$ Mean value was significantly different from that of the reference group $(P<0.05$; Dunnett's test).

†By Student's $t$ test or ANOVA comparing mean 18:2n-6:18:3n-3 ratio or 18:2n-6 and 18:3n-3 intakes in g/d or as a proportion of total El. 
women with low educational achievement ${ }^{37}$. Indeed, a notably lower carbohydrate intake ( 38 to $40 \%$ of EI) was observed in a population of younger French individuals ${ }^{48}$. The proportion of proteins was on average higher than the recommendation (about 10 to $15 \%$ of total EI). In younger French adults, Czernichow et al. reported a similar protein intake (16 to $17 \%$ of EI $)^{48}$. However, the protein intake decreased with age and almost half of the population enrolled in the present study ate less than $1 \mathrm{~g}$ protein/kg body weight per $\mathrm{d}$. Taking into account that lower weights were observed in the oldest group, these observations suggest that some protein-energy malnutrition occurs in the oldest individuals, putting them at risk of sarcopenia $^{49}$. It is worth noting that foods from animal protein sources are generally high in fats, particularly in saturated fat and cholesterol. In the average French adult diet, 30 to $35 \%$ of energy was estimated to come from total $\mathrm{fat}^{8}$, which is the case in the population sample enrolled in the present study but notably lower than the values found in younger French adults where 36 to $40 \%$ of EI comes from total fat in men and women aged no more than 65 years ${ }^{14,48,50}$. In the present study, as previously described by Willett $e t \mathrm{al}^{24}$, an inverse association between the $\ln$ (TAG) and total fat intake was observed whereas the food questionnaire completion and blood collection were within 2 years of each other and not 1 year as Willett et al. ${ }^{24}$ This result could be interpreted as a relative stability of dietary intake of the elderly during these 2 years. Concerning saturated fat, the consumption was almost twice higher than recommendations ( $8 \%$ of EI) as already observed in the elderly ${ }^{37}$ and also reported in the literature for French adult consumers ${ }^{50}$. According to these authors, the higher intake of saturated fat is largely the consequence of high intakes of butter, cheese, meat products and baked products. Indeed, $93 \%$ of the population enrolled in the Three-City Study were regular consumers of dairy products ${ }^{18}$. Hence, the common opinion of the elderly French that 'there is no good meal without cheese' seems to be held in the population studied. Recent analysis on dietary habits among Americans reported that they consumed too much saturated fat, as was observed in the present study in French elderly individuals ${ }^{51}$. Moreover, we observed that the excess of saturated fat was associated with a relative deficit in MUFA consumption, compared with the dietary allowances (about $20 \%$ of EI). Concerning PUFA, the intake of $18: 3 n-3$, despite it being an essential fatty acid, was below the recommendations (about $0.8 \%$ of EI) and quantitatively comparable with that observed by others in a younger French population ${ }^{14}$. As a consequence, the $18: 2 n$ $6: 18: 3 n-3$ ratio is fairly high ( 9.90 on average) and close to the ratio observed in younger populations ${ }^{14}$. The very large range of intake and the asymmetric quartiles of distribution for EPA and DHA have already been observed in various studies and countries ${ }^{14}$. Knowing that the main source of EPA and DHA is fish, a food not consumed daily in the ThreeCity cohor ${ }^{52}$, this result might also be due in part to the single $24 \mathrm{~h}$ recall used which allows a good estimation of the mean but not of the variance of the consumption. The analysis of the FFQ assessed at wave 2 allowed us to ensure that in this sample the fish consumption frequency was linked to the estimated EPA and DHA intake (Spearman coefficient; $r$ 0.16; $P<0.0001)$. As well, the analysis of the FFQ allowed us to identify about $17.3 \%$ of subjects who consumed only rarely (i.e. less than once per week) poultry or eggs which are rich in $20: 4 n-6$. This pattern of food consumption could explain the large distribution of arachidonic acid intake observed in this sample of elderly and not mentioned by others in younger French populations ${ }^{14}$. Indeed, there was a significant correlation between the poultry or egg consumption estimated by FFQ and the 20:4 intake (Spearman coefficient; $r$ 0.12; $P<0 \cdot 0001)$. Since essential $n-6$ and $n-3$ fatty acid intakes were below the recommendations and that the biosynthesis of long-chain PUFA occurs only at a very low rate and seems to decrease with age $\mathrm{e}^{10,11}$, the intake of long-chain PUFA seems to be insufficient for a non-negligible part of the sample compared with the recommendations. Moreover, the present findings indicate a statistical association between educational level and the $18: 2 n-6: 18: 3 n-3$ ratio in the elderly. A difference from 9.35 to 10.64 of this ratio between the lowest educated subjects and subjects with a higher educational level seems apparently too small to have any nutritional consequences. However, the effects of $n-3$ PUFA intake or educational level on age-related disorders such as dementia have already been demonstrated ${ }^{2-6,53}$. Likewise, marital status was associated with the intake of the precursor of $n-6$ PUFA. Knowing that the intake of long-chain $n-3$ fatty acids was correlated to indicators for healthy dietary habits ${ }^{54}$, socio-demographic characteristics, such as marital status and education, associated with inadequate intake of fatty acids could be considered as markers of vulnerability in the elderly.

Thanks to the present cross-sectional study, it was possible to identify socio-demographic characteristics associated with quantitatively and qualitatively poor dietary patterns in a French elderly group. Older individuals at risk of malnutrition, mainly women, the very elderly, the widowed or single subjects, or individuals with low educational or income level, all of whom seem particularly vulnerable to age-related diseases, should be targeted for nutritional counselling. Our findings suggest that the elderly of southwestern France have an unbalanced fatty acid intake, characterised by, on average, an excessive intake of saturated fats related to a deficit of MUFA and PUFA, notably in $n$-3, intake.

\section{Acknowledgements}

The Three-City Study is conducted under a partnership agreement between the Institut National de la Santé et de la Recherche Médicale (INSERM), Victor Segalen - Bordeaux 2 University and the company Sanofi-Synthélabo. The Fondation pour la Recherche Médicale funded the preparation and beginning of the study. The Three-City Study is also sponsored by the Caisse Nationale Maladie des Travailleurs Salariés, Direction Générale de la Santé, Conseils Régionaux of Aquitaine and Bourgogne, Fondation de France, Ministry of Research-INSERM Programme 'Cohortes et collections de données biologiques'. The Conseil Régional d'Aquitaine also contributed to the funding of the dietary data.

C. F.'s research was sponsored by a grant from Conseil Régional d'Aquitaine. None of the authors had any financial or personal conflicts of interest. C. F. contributed to the analysis of data and the writing of the manuscript. M. A. J. contributed to the design of the experiment, collection of data and the providing of significant advice. S. L. contributed to 
the design of the experiment and collection of data. L. L. contributed to the design of the experiment, collection of data and the providing of significant advice. C. D. contributed to the design of the experiment, and the providing of significant advice. N. C. contributed to the collection of specific data on fatty acids. P. B.-G. contributed to the design of the experiment, collection and analysis of data, and to the writing of the manuscript. All the authors made a critical revision of the draft.

\section{References}

1. Trichopoulou A \& Vasilopoulou E (2004) Mediterranean diet and longevity. Br J Nutr 84, S205-S209.

2. Wendland E, Farmer A, Glasziou P \& Neil A (2006) Effect of $\alpha$ linolenic acid on cardiovascular risk markers: a systematic review. Heart 92, 166-169.

3. Larsson SC, Kumlin M, Ingelman-Sundberg M \& Wolk A (2004) Dietary long-chain $n-3$ fatty acids for the prevention of cancer: a review of potential mechanisms. Am J Clin Nutr 79, 935-945.

4. Bourre JM (2005) Dietary omega-3 fatty acids and psychiatry: mood, behaviour, stress, depression, dementia and aging. J Nutr Health Aging 9, 31-38.

5. Barberger-Gateau P, Letenneur L, Deschamps V, Peres K, Dartigues JF \& Renaud S (2002) Fish, meat, and risk of dementia: cohort study. BMJ 325, 932-933.

6. Bruinsma KA \& Taren DL (2000) Dieting, essential fatty acid intake, and depression. Nutr Rev 58, 98-108.

7. Simopoulos AP, Leaf A \& Salem N Jr (2000) Workshop statement on the essentiality of and recommended dietary intakes for omega-6 and omega-3 fatty acids. Prostaglandins Leukot Essent Fatty Acids 63, 119-121.

8. Martin A (2001) The 'apports nutritionnels conseilles (ANC)' for the French population. Reprod Nutr Dev 41, 119-128.

9. Burdge GC \& Calder PC (2005) Conversion of $\alpha$-linolenic acid to longer-chain polyunsaturated fatty acids in human adults. Reprod Nutr Dev 45, 581-597.

10. Imre S, Firbas JH \& Noble RC (2000) Reduced lipid peroxidation capacity and desaturation as biochemical markers of aging. Arch Gerontol Geriat 31, 5-12.

11. Bourre JM (2004) Roles of unsaturated fatty acids (especially omega-3 fatty acids) in the brain at various ages and during ageing. J Nutr Health Aging 8, 163-174.

12. Institut National de la Statistique et Des Etudes Economiques (2006) France en faits et chiffres - espérance de vie à divers âges (France in facts and figures - life expectency at various ages). Version current 1 September 2006. http://www.insee.fr/ fr/ffc/chifcle_fiche.asp?ref_id = NATCCF02207\&tab_id $=10$ (accessed September 2006).

13. Lioret S, Dubuisson C, Gautier A, Perrin-Escalon H, Guilbert P, Volatier J \& Delamaire C (2004) Comparaison de Deux Enquêtes Nationales de Consommation Alimentaire auprès des Adolescents et des Adultes - Baromètre Santé Nutrition (2002) et INCA (1998-99): Eléments de Méthode et Résultats. Paris: Agence Française de Sécurité Sanitaire des Aliments, Institut National de Prévention et d'Education pour la Santé.

14. Astorg P, Arnault N, Czernichow S, Noisette N, Galan P \& Hercberg S (2004) Dietary intakes and food sources of $n-6$ and $n$-3 PUFA in French adult men and women. Lipids 39, 527-535.

15. Hooper L, Thompson RL, Harrison RA, et al. (2006) Risks and benefits of omega 3 fats for mortality, cardiovascular disease, and cancer: systematic review. BMJ 332, 752-760.
16. Ferrieres J (2004) The French paradox: lessons for other countries. Heart 90, 107-111.

17. 3C Study Group (2003) Vascular factors and risk of dementia: design of the Three-City Study and baseline characteristics of the study population. Neuroepidemiology 22, 316-325.

18. Larrieu S, Letenneur L, Berr C, Dartigues JF, Ritchie K, Alperovitch A, Tavernier B \& Barberger-Gateau P (2004) Sociodemographic differences in dietary habits in a population-based sample of elderly subjects: the 3C study. $J$ Nutr Health Aging 8, 497-502.

19. SU.VI.MAX (2000) Portions Alimentaires. Manuel Photos Pour L'estimation des Quantités. Paris: Diffusion Economica.

20. Hercberg S, Preziosi P, Briancon S, Galan P, Triol I, Malvy D, Roussel AM \& Favier A (1998) A primary prevention trial using nutritional doses of antioxidant vitamins and minerals in cardiovascular diseases and cancers in a general population: the SU.VI.MAX study - design, methods, and participant characteristics. Supplementation en VItamines et Mineraux AntioXydants. Control Clin Trials 19, 336-351.

21. Favier J, Ireland-Ripert J, Toque C \& Feinberg M (1995) Répertoire Général des Aliments. Table de Composition, 2nd ed. Paris: INRA Editions.

22. Souci S, Fachman W \& Kraut H (2000) Food Composition and Nutrition Tables. Stuttgart: Medpharm Scientific Publishers.

23. Renaud S, Godsey F, Ortchanian E \& Baudier F (1979) Table de Composition des Aliments. Courbevoie, France: ASTRACALVE.

24. Willett W, Stampfer M, Chu NF, Spiegelman D, Holmes M \& Rimm E (2001) Assessment of questionnaire validity for measuring total fat intake using plasma lipid levels as criteria. Am J Epidemiol 154, 1107-1112.

25. Guigoz Y, Vellas B \& Garry PJ (1996) Assessing the nutritional status of the elderly: the Mini Nutritional Assessment as part of the geriatric evaluation. Nutr Rev 54, S59-S65.

26. Heiat A, Vaccarino V \& Krumholz HM (2001) An evidencebased assessment of federal guidelines for overweight and obesity as they apply to elderly persons. Arch Intern Med 161, 1194-1203.

27. Deschamps V, Astier X, Ferry M, Rainfray M, Emeriau JP \& Barberger-Gateau P (2002) Nutritional status of healthy elderly persons living in Dordogne, France, and relation with mortality and cognitive or functional decline. Eur J Clin Nutr 56, 305-312.

28. Henry CJ (2001) Basal Metabolic Rate Studies in Humans: Measurement and Development of New Equations. Background document prepared for the joint FAO/WHO/UNUExpert consultation on energy in human nutrition. Rome: FAO.

29. Fraser GE (2003) A search for truth in dietary epidemiology. Am J Clin Nutr 78, Suppl. 3, 521S-525S.

30. Johansson G, Wikman A, Ahren AM, Hallmans G \& Johansson I (2001) Underreporting of energy intake in repeated 24-hour recalls related to gender, age, weight status, day of interview, educational level, reported food intake, smoking habits and area of living. Public Health Nutr 4, 919-927.

31. Willett W (1998) Nutritional Epidemiology, 2nd ed. New York and Oxford: Oxford University Press.

32. Bingham SA (1991) Limitations of the various methods for collecting dietary intake data. Ann Nutr Metab 35, 117-127.

33. Livingstone MB \& Black AE (2003) Markers of the validity of reported energy intake. J Nutr 133, Suppl. 3, 895S-920S.

34. Ramirez-Zea M (2005) Validation of three predictive equations for basal metabolic rate in adults. Public Health Nutr 8, 1213-1228.

35. Henry CJ (2005) Basal metabolic rate studies in humans: measurement and development of new equations. Public Health Nutr 8, 1133-1152. 
36. Koehler KM, Hunt WC \& Garry PJ (1992) Meat, poultry, and fish consumption and nutrient intake in the healthy elderly. $J$ Am Diet Assoc 92, 325-330.

37. Bamia C, Orfanos P, Ferrari P, et al. (2005) Dietary patterns among older Europeans: the EPIC-Elderly study. Br J Nutr 94, 100-113.

38. Drewnowski A, Henderson SA, Shore AB, Fischler C, Preziosi $P$ \& Hercberg S (1997) The fat-sucrose seesaw in relation to age and dietary variety of French adults. Obes Res 5, 511-518.

39. Ocke M, Bueno-de-Mesquita H, Goddijn H, Jansen A, Pols M, van Staveren W \& Kromhout D (1997) The Dutch EPIC food frequency questionnaire. I. Description of the questionnaire, and relative validity and reproducibility for food groups. Int $J$ Epidemiol 26, Suppl. 1, 37S-48S.

40. Walls AW \& Steele JG (2004) The relationship between oral health and nutrition in older people. Mech Ageing Dev 125, 853-857.

41. Greenwald DA (2004) Aging, the gastrointestinal tract, and risk of acid-related disease. Am J Med 117, Suppl. 5A, 8S-13S.

42. Roberts SB \& Rosenberg I (2006) Nutrition and aging: changes in the regulation of energy metabolism with aging. Physiol Rev 86, 651-667.

43. Kennedy ET (2006) Evidence for nutritional benefits in prolonging wellness. Am J Clin Nutr 83, 410S-414S.

44. Trabulsi J \& Schoeller DA (2001) Evaluation of dietary assessment instruments against doubly labeled water, a biomarker of habitual energy intake. Am J Physiol Endocrinol Metab 281, E891-E899.

45. Kant AK (2003) Interaction of body mass index and attempt to lose weight in a national sample of US adults: association with reported food and nutrient intake, and biomarkers. Eur J Clin Nutr 57, 249-259.

46. Darmon N, Briend A \& Drewnowski A (2004) Energy-dense diets are associated with lower diet costs: a community study of French adults. Public Health Nutr 7, 21-27.

47. Launer LJ (2005) The epidemiologic study of dementia: a lifelong quest? Neurobiol Aging 26, 335-340.

48. Czernichow S, Bruckert E, Oppert JM, Bertrais S, Paillard F, Astorg P, Arnault N, Galan P \& Hercberg S (2005) Intake of added oils and fats among middle-aged French adults: relationships with educational level and region of residence. $J$ Am Diet Assoc 105, 1889-1894.

49. Fujita S \& Volpi E (2006) Amino acids and muscle loss with aging. J Nutr 36, Suppl. 1, 277S-280S.

50. Volatier JL \& Verger P (1999) Recent national French food and nutrient intake data. Br J Nutr 81, Suppl. 2, S57-S59.

51. German JB \& Dillard CJ (2004) Saturated fats: what dietary intake? Am J Clin Nutr 80, 550-559.

52. Barberger-Gateau P, Jutand MA, Letenneur L, Larrieu S, Tavernier B \& Berr C (2005) Correlates of regular fish consumption in French elderly community dwellers: data from the Three-City study. Eur J Clin Nutr 59, 817-825.

53. Ott A, van Rossum CTM, van Harskamp F, van de Mheen H, Hofman A \& Breteler MMB (1999) Education and the incidence of dementia in a large population-based study: The Rotterdam Study. Neurology 52, 663-666.

54. Johansson LR, Solvoll K, Bjorneboe GE \& Drevon CA (1998) Intake of very-long-chain $n-3$ fatty acids related to social status and lifestyle. Eur J Clin Nutr 52, 716-721. 